\title{
Using an integrated method to estimate watershed sediment yield during heavy rain period: a case study in Hualien County, Taiwan
}

\author{
S. M. Hsu ${ }^{1}$, H. Y. Wen ${ }^{1}$, N. C. Chen ${ }^{1}$, S. Y. Hsu' ${ }^{2}$, and S. Y. Chi ${ }^{1}$ \\ ${ }^{1}$ Geotechnical Engineering Research Center, Sinotech Engineering Consultants, Inc., Taipei, Taiwan \\ ${ }^{2}$ Department of Water and Soil Conservation, National Chung Hsing University, Taichung, Taiwan
}

Correspondence to: S. M. Hsu (shihmeng@ sinotech.org.tw)

Received: 16 December 2011 - Revised: 25 May 2012 - Accepted: 25 May 2012 - Published: 18 June 2012

\begin{abstract}
A comprehensive approach estimating sediment yield from a watershed is needed to develop better measures for mitigating sediment disasters and assessing downstream impacts. In the present study, an attempt has been made to develop an integrated method, considering sediment supplies associated with soil erosion, shallow landslide and debris flow to estimate sediment yield from a debris-flow-prone watershed on a storm event basis. The integrated method is based on the HSPF and TRIGRS models for predicting soil erosion and shallow landslide sediment yield, and the FLO2D model for calculating debris flow sediment yield. The proposed method was applied to potential debris-flow watersheds located in the Sioulin Township of Hualien County. The available data such as hourly rainfall data, historical streamflow and sediment records as well as event-based landslide inventory maps have been used for model calibration and validation. Results for simulating sediment yield have been confirmed by comparisons of observed data from several typhoon events. The verified method employed a 24-h design hyetograph with the 100 -yr return period to simulate sediment yield within the study area. The results revealed that the influence of shallow landslides on sediment supply as compared with soil erosion was significant. The estimate of landslide transport capacity into a main channel indicated the sediment delivery ratio on a typhoon event basis was approximately $38.4 \%$. In addition, a comparison of sediment yields computed from occurrence and non-occurrence of debris flow scenarios showed that the sediment yield from an occurrence condition was found to be increasing at about 14.2 times more than estimated under a non-occurrence condition. This implied watershed sediment hazard induced by debris flow may cause severe consequences.
\end{abstract}

\section{Introduction}

Taiwan is located at the junction of the Eurasian and Philippine Sea plates. The geologic characteristics of this area are frequent geological activities, young geological age, fragile rocks, and complicated geological structures. Torrential precipitation events may easily trigger landslides, slope sliding, and debris flow. This would in turn lead to sediment-related disasters and cause damage to buildings, resulting in fatalities, severe injuries to the residents, or sedimentation impacts to reservoirs. Thus, information on sediment yield analysis from a watershed is very often required for hazard mitigation and watershed management purposes.

Sediment yield is dependent on all variables that control erosion and sediment delivery, including local topography, soil, geology, climate, vegetation, catchment morphology, land use and drainage network characteristics (Verstraeten and Poesen, 2001). The watershed sediment yield system is, in general, very complex and highly nonlinear, having temporal and spatial variability so that the sediment yield estimate has become a challenge task. In the past, the sediment yield has been estimated by sediment discharge measurement data coupled with the sediment rating curve. However, monitoring is time-consuming and expensive. Modelling gives an alternative method for estimation and understanding of sediment erosion and transport, and can also be used to investigate potential impacts for possible future climate scenarios (Chou, 2010). Many models for predicting soil erosion and estimating sediment yield have been developed, such as AGNPS (Young et al., 1989), ANSWERS (Beasley et al., 1980), CREMS (Knisel, 1980), EUROSEM (Morgan et al., 1998), HSPF (Johanson et al., 1980), KINEROS (Smith, 1981), LASCAM (Viney and Sivapalan, 1999), SEDNET (Prosser 
et al., 2001), SHESED (Wicks and Bathurst, 1996), SWAT (Amold et al., 1998), USLE (Wischmeier and Smith, 1978) and WEEP (Laflen et al., 1991), and are used widely all over the world (Amore et al., 2004; Bhayan, et al., 2002; Chou, 2010; Nasr et al., 2007; Ziegler et al., 2001). Merritt et al. (2003) and Aksoy and Kavvas (2005) gave an excellent review for various models applicable in sediment transport and erosion modelling, in which the reviewed models can be categorized into two groups: empirical and physicallybased frameworks. However, these models exist for the consideration of soil erosion. For steep hillslopes, rainfall events on the environment can cause both soil erosion and shallow landslides. Shallow landslides can be significant sources of sediment in hilly catchments, and may in turn act as a major control on the occurrence of debris flow in rivers (Selby, 1993; Istanbulluoglu et al., 2004; Schwab et al., 2008; Lin et al., 2011). Several studies have tended to exploit the influence of shallow landslides on sediment supply or to develop appropriate models for determining sediment yield arising from shallow landsliding (Allen and Hovius, 1998; Burton and Bathurst, 1998; Bathurst et al., 2006; Schuerch et al., 2006; Claessens et al., 2007; Acharya et al., 2009, 2011). They all recognized that landslides play an important role in determining the sediment yield of hilly catchments, and the development of shallow landslide sediment yield models is still in the stage of infancy as compared with the soil erosion models.

In addition, total sediment yield arising from shallow landslides depends on the transport process of failure material to the channel network. If the material evolves into a debris flow, the sediment volume is relatively high in magnitude (Malet et al., 2005). These processes of soil erosion, landslides, and debris flow interact with each other and thus need to be studied in an integrated way to understand hillslope sediment yield. Thus, a feasible method to predict sediment yield should take into account possible sediment sources and transport mechanisms. This effort may enhance the capacity and accuracy in assessing possible impacts of sedimentrelated disasters.

In this study, the aim of this research is to propose an integrated method, taking advantages of existing simulation models by considering sediment supplies associated with soil erosion, shallow landslide and debris flow to estimate sediment yield on a storm event basis in hilly watersheds, in particular in debris-flow-prone watersheds. The integrated method is based on the HSPF (Johanson et al., 1980) and TRIGRS models (Baum et al., 2002) for predicting soil erosion and shallow landslide sediment yield, and the FLO-2D model (O’Brien, 2006) for calculating debris flow sediment yield. A case study to demonstrate potential impacts on sediment yield from different sediment sources is presented. This paper also discusses landslide sediment delivery ratio and relationship between sediment yield and watershed area.

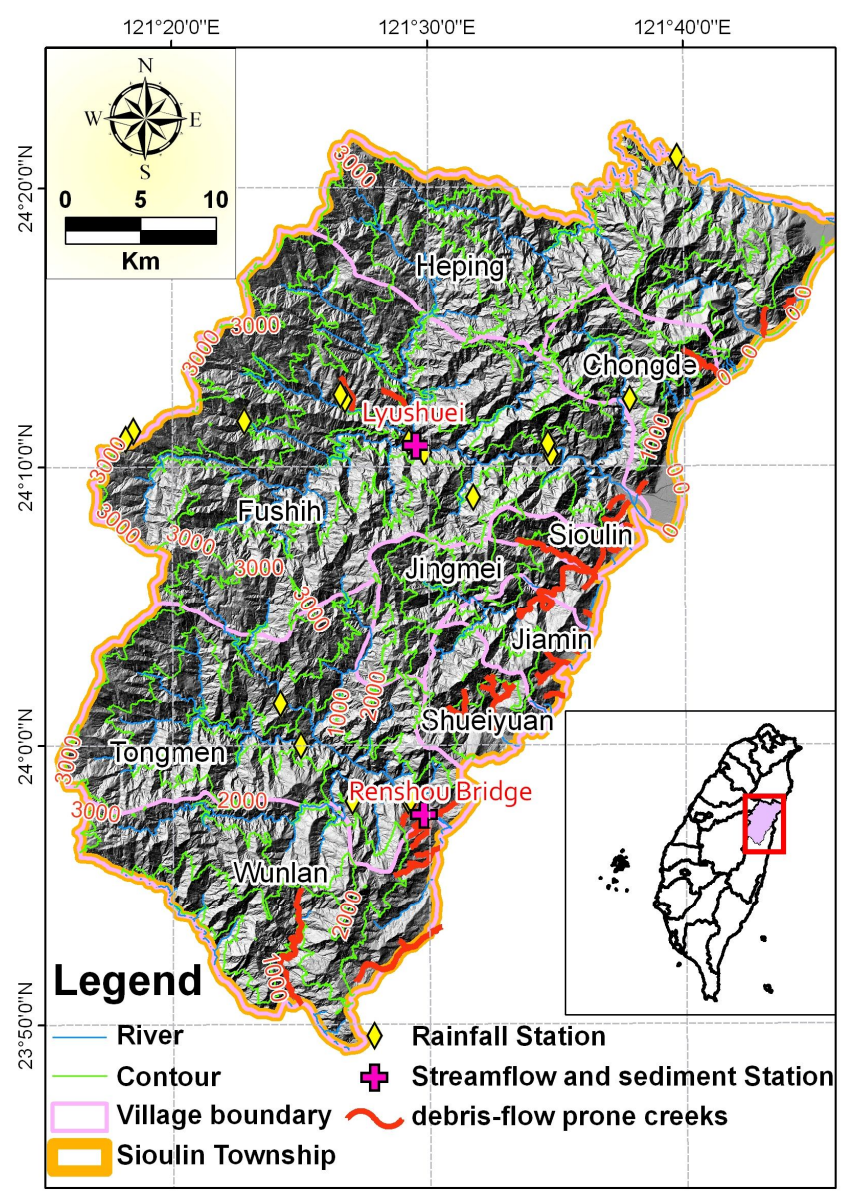

Fig. 1. Location of study area and distribution of debris-flow-prone creeks at Sioulin Town.

\section{The study area}

The study area is located at the Sioulin Town in Hualien County on the eastern coast of Taiwan, as shown in Fig. 1. Sioulin Town faces the immense Pacific Ocean to the east and leans against the grand Central Mountain Range in the west. The area is on the boundary of the Philippine and Eurasian Plates. As a result of the collision of two plates, metamorphic rocks typically prevail in the area. Additionally, the sea terraces, river terraces, alluvial fans, meanders, and a river valley basin can be easily seen within the region.

The Sioulin Town is mountainous with a long and narrow territory. The area below a $100 \mathrm{~m}$ elevation consists $3 \%$ of the town's land area. The terrain with a hillslope angle less than $5 \%$ covers $0.08 \%$. Because of the limited plain areas, urban development on slopeland has become inevitable. Typhoons with heavy rainfall frequently strike Sioulin Town every year during the period mainly from June to October and bring bountiful rainfall. Because of these geomorphological and hydrological characteristics, sediment-related disasters such as landslides or debris flows prevail in the region during typhoon season. Figure 1 shows the distribution of 


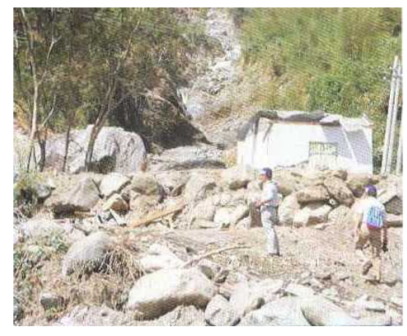

(a) destroyed houses and debris flow deposits

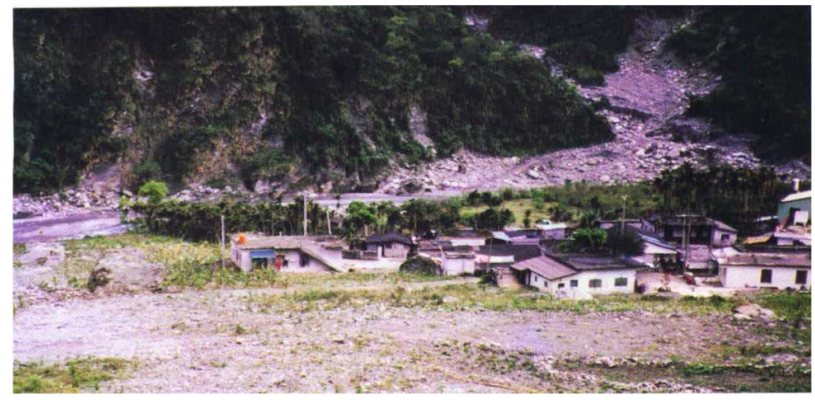

(c) far view of Tongmen Village, shallow landsliding and debris flow deposition

Fig. 2. Landslide and debris flow disaster caused by Typhoon Ofelia occurring on 22 June 1990 in Tongmen Village.

potential debris-flow creeks at Sioulin Town. Out of 162 potential debris-flow creeks in Hualien County, the town contains 26 creeks spread throughout 9 villages. In the past, landslides and debris flows occurred in some of the debris-flowprone creeks, especially in the villages of Tongmen, Jingmei, Fushih and Heping and resulted in casualties and serious property damage. Figure 2 shows a devastating debrisflow calamity caused by Typhoon Ofelia in 1990 which occurred in Tongmen Village. The typhoon brought heavy rainfall with maximum rainfall intensity of $95.5 \mathrm{~mm} \mathrm{~h}^{-1}$ and a 3-day accumulated rainfall of about $835 \mathrm{~mm}$, triggering landslides that mobilized a large amount of slope material which transformed into debris flows. According to the official disaster statistics issued by the Hualien office of the Soil and Water Conservation Bureau, the event produced approximately $55000 \mathrm{~m}^{3}$ of rock and debris that flowed down to the guarded areas and killed 38 people, as well as buried 227 houses.

\section{Methodology}

\subsection{Framework of sediment yield estimates}

A combination of fluvial and hillslope processes occurs in debris-flow-prone creeks, making the estimation of sediment yield complicated. A comprehensive approach for estimating sediment yield may consider the following four components: (1) model simulation based on storm event rainfall data; (2) non-point source of sediment from erosion; (3) point source of sediment from shallow landsliding; (4) transport

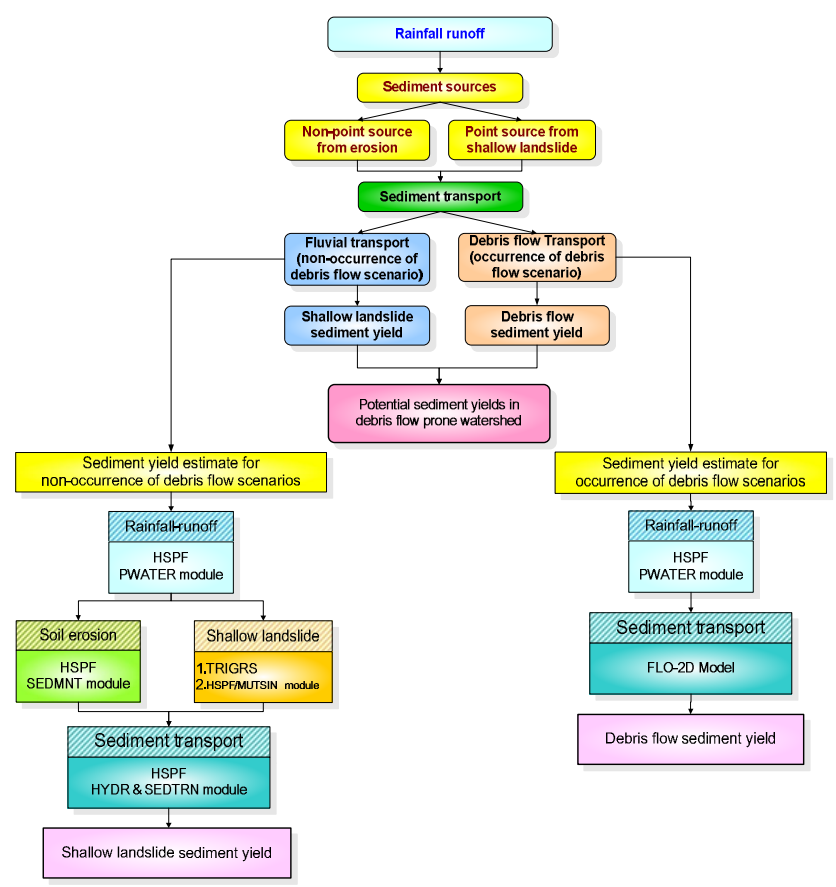

Fig. 3. A holistic framework for sediment yield estimate in hilly watershed.

mechanisms for both fluvial transport and debris flow scenarios. A detailed flowchart of sediment yield estimate is illustrated in Fig. 3 (the upper part of this Figure). This flowchart mainly includes three processes: rainfall-runoff, sediment erosion and incidence of shallow landsliding, and sediment transport by runoff. The integrated method starts with a rainfall-runoff process. Subsequently, sediment is detached from soil surface both by raindrop impact and the shearing force of flowing water. On the other hand, water may seep into the ground during heavy rainfall and saturate the sublayers of the slope. When the pore water pressure is sufficient to decrease effective normal stress to a critical level, slope failure occurs. Finally, the eroded sediment and failed materials are transported down the slope primarily by the flowing water. During the propagation, a few factors, including rainfall intensity, local topography, soil characteristics, drainage network, and slope morphology will determine a dominant transport process. This could be in the regime of fluvial transport or debris flow transport. If the debris flow happens, the downstream impact is more significant than that of fluvial flow. Based on the framework, both soil erosion and shallow landslides were studied in an integrated way to estimate sediment yields. In addition, modelling frameworks for both occurrence and non-occurrence of debris flow scenarios were developed. 


\subsection{Estimation of shallow landslide sediment yield (non-occurrence condition)}

The procedure for estimating shallow landslide sediment yield has been developed as shown in Fig. 3 (the lower lefthand side of the Figure). The method used and developed in this study, including model descriptions, calibration, verification, and simulation procedure are given as follows.

\subsubsection{HSPF model background}

For the shallow landslide sediment yield modelling, the Hydrological Simulation Program - FORTRAN (HSPF) model version 12 was applied. HSPF was selected for the purpose of the present study because the numerical model over most existing models can take into account both point and nonpoint source of sediment as mentioned in Sect. 3.1. HSPF is a comprehensive watershed model that simulates non-point sources runoff and pollutant loadings for a watershed, combines these with point sources contribution and models flow and water quality transport and fate. A detailed description of the HSPF model, including model introduction, data requirements, assumptions, and limitations of the model, can be found in the model user manual (Bicknell et al., 2001). This section presents a brief summary of the hydrological and sediment transport processes simulated by HSPF.

HSPF is based upon the Stanford Watershed Model and evolved out of three previously developed models: (1) the USEPA Agricultural Runoff Management (ARM) model, (2) Non-point Sources Runoff model (NPS), and (3) Hydrological Simulation Program (HSP). This model comprises three primary modules: (a) Pervious Land-segment module (PERLND), (b) Impervious Land-segment module (IMPLND), and (c) Free-flowing Reach or Mixed Reservoirsegment module (RCHRES). HSPF makes use of PERLAND to simulate water quality and quantity processes that occur on a pervious land segment. IMPLND is the module that simulates hydrological processes on an impervious segment. The RCHRES module simulates the processes that occur in a single reach of open or closed channel, or a completely mixed lake. Each module consists of a couple of submodules. The principle modules used in this study are the PERLND and RCHRES modules. In the PERLND module, the sub-modules PWATER and SEDMNT were used to compute the components of water budget and to simulate the production and removal of sediment from a pervious area, respectively. In the RCHRES module, the sub-modules HYDR and SEDTRN were utilized to simulate the hydraulic behaviour of the stream and to perform the transport, deposition, and scour of sediment in free-flowing reaches, respectively.

\subsubsection{Prediction of shallow landslide}

A variety of approaches has been utilized to determine rainfall-induced shallow landslides, such as empiricalstatistical methods (e.g. Reichenbach et al., 1998; Godt et al., 2006) or physically-based methods (e.g. Montgomery and Dietrich, 1994; Baum et al., 2002). However, the empiricalstatistical approach ignores the physical process by which rainfall infiltration affects the stability of the hillslopes and limits the ability to predict the hazard. In this study, the Transient Rainfall Infiltration and Grid-based Slope-stability (called TRIGRS), which is developed by the USGS (Baum et al., 2002), was adopted to investigate the landslide susceptibility. The model is a coupled hydromechanical slope stability assessment tool, working on a regional scale. TRIGRS is raster-based and uses a time-dependent approach to assess the stability of a basin during a rainfall event. Infiltration is modelled through a simplified analytical solution of Richards' equation (Iverson, 2000), which requires a shallow, quasi-saturated soil cover at the beginning of a simulation. The built-up pore pressure is then used as an input to a slope stability model, based on the infinite slope approach. The main output of TRIGRS is a factor of safety, indicating whether the slope can be considered stable or not. Details of the model equations and detailed parameters description can be found in the model's user manual (Baum et al., 2002).

Since TRIGRS is a physically-based model, a large number of parameter values need to be given and addressed. Parametric analyses to test the model and show the effect of parameter variation on the distribution of simulated instability in the study area were conducted. Results showed that the most sensitive parameters in the model were effective cohesion and the hydraulic conductivity. This gave a reference in calibration process.

Data required for model simulation include rainfall, digital elevation model (DEM) of the study area, effective cohesion, friction angle, soil unit weight, water unit weight, topographic slope, initial water table depth, soil thickness, hydraulic conductivity, hydraulic diffusivity, and long-term infiltration rate, where the slope can be computed by means of grid DEM ( $20 \mathrm{~m}$ resolution); the spatial distribution of soil thickness can be determined by a linear relationship between the wetness index and soil thickness (Lee and Ho, 2009); the initial water table depth can be obtained from the relative wetness index in the Stability Index Mapping (SINMAP) model (Pack et al., 2005); the long-term infiltration rate can be acquired from the streamflow partitioning (PART) program (Rutledge, 1992); the hydraulic diffusivity value is assumed to be 400 times the hydraulic conductivity of soil (Baum et al., 2002); the effective cohesion, friction angle, and hydraulic conductivity can be calibrated against observed data.

An inventory map of shallow landslide occurrence in the study area from two typhoon events as shown in Fig. 4 were available for the purpose of model calibration and validation, 

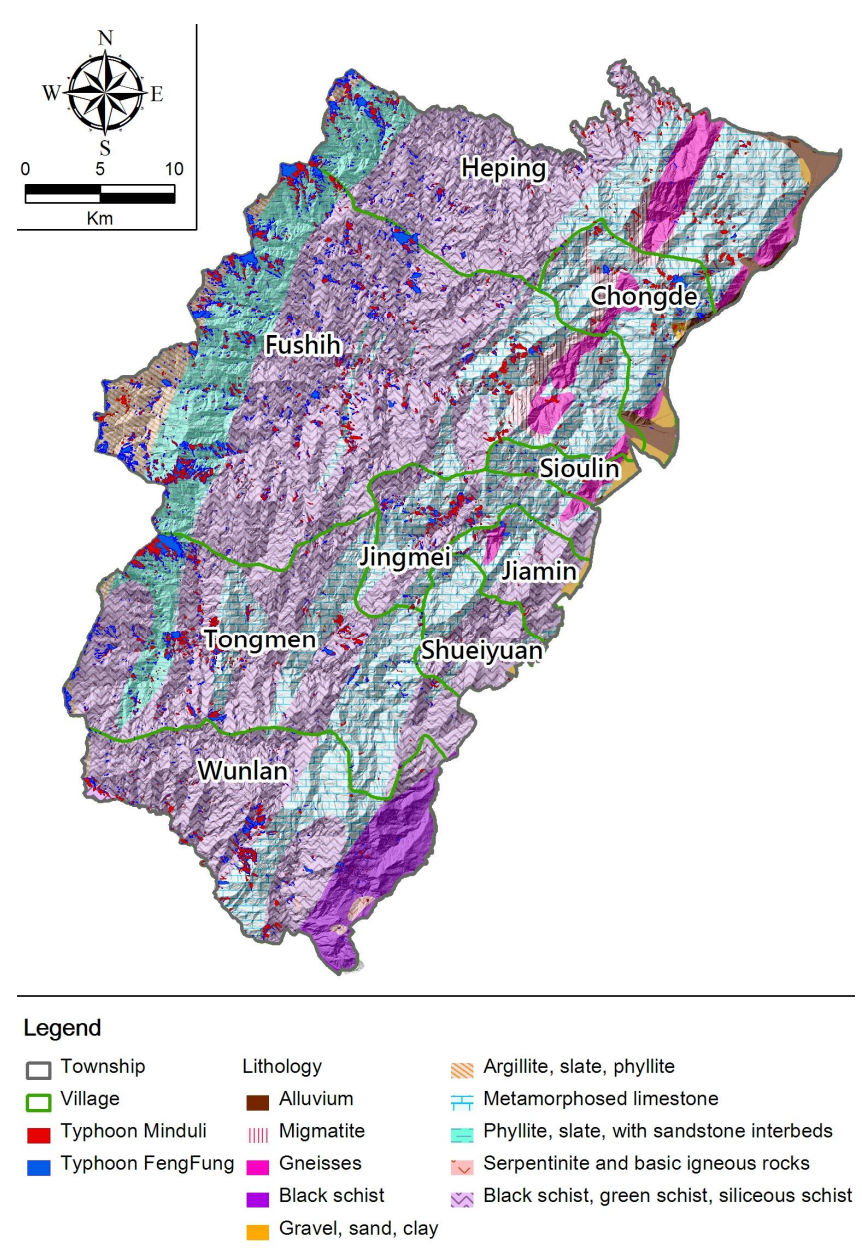

Fig. 4. Inventory map of a shallow landslide triggered by two typhoon events and geological map of study area.

where landslide occurrence data from Typhoon Minduli was applied to the model calibration; landslide occurrence data from Typhoon Fenghung was applied to the model validation. To simplify the calibration process, the study area was divided into ten zones based on the geological map and lithology as shown in Fig. 4 so that the given parameters can be uniformly applied to each zone. A flowchart showing the steps for the model calibration can be found in Fig. 5. As shown in Fig. 5, the aim of the calibration was to reproduce the observed occurrence of landslides as accurately as possible with the simulation. Three criteria must be obeyed in the calibration process, including (1) the factor of safety (FS) must initially be greater than unity for the entire study area before any rainfall; (2) the simulated landslide rate (SLR) for each geologic zone (see Fig. 6) should be close to the observed landslide rate (OLR); (3) the accuracy rate of the model for each zone should be greater than $85 \%$. By adjusting values of the calibrated parameters in the model to fit the observed data, the calibration results indicate the error between simulated and observed landslides for each zone

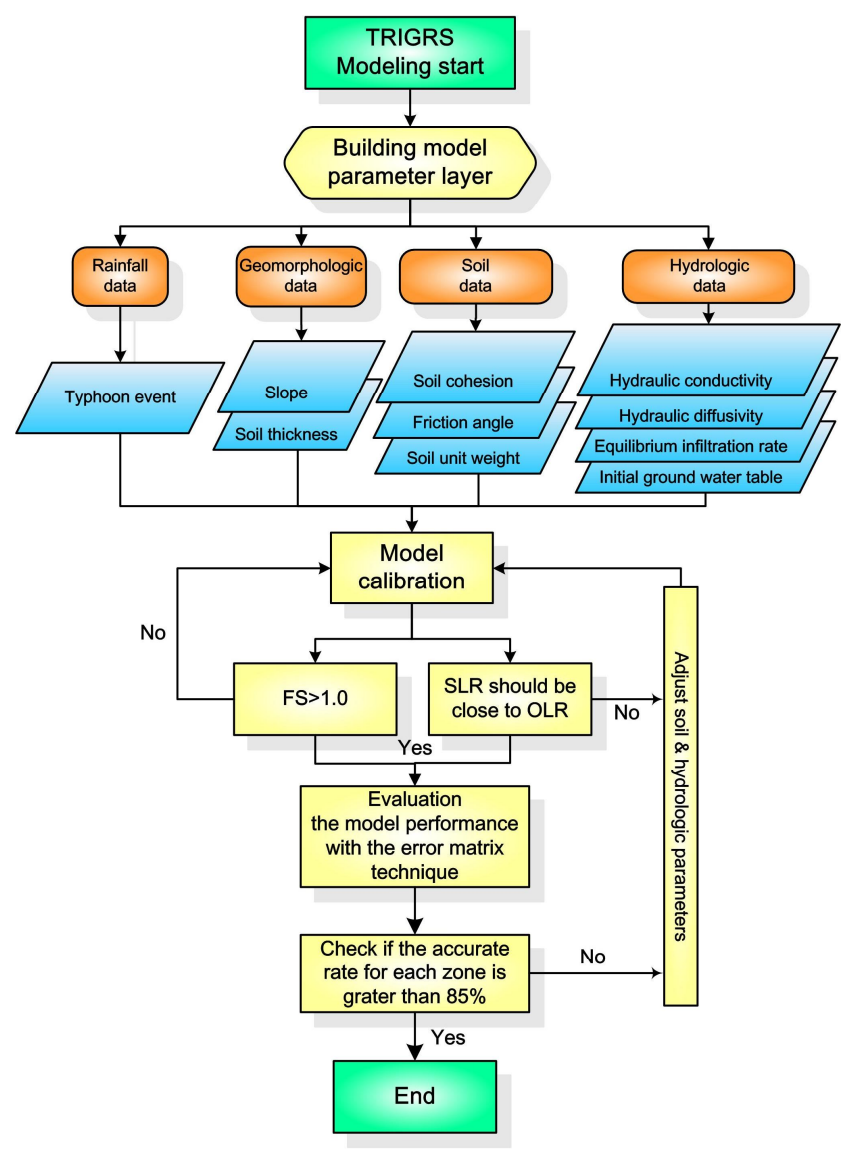

Fig. 5. Flowchart for model calibration

ranges from $1 \%$ to $11 \%$, which is less than the targeted value of $15 \%$. Subsequently, we replicated shallow landslide occurrence caused by Typhoon Fenghung in order to verify the accuracy of the presented model. Comparing the results with the shallow landslide inventory map, for the study as a whole, we found $93.92 \%$ agreement between predicted shallow landslide susceptibility and the inventory. Finally, the landslide volume can be estimated by multiplying the landslide area by the soil depth.

\subsubsection{Sensitivity analysis for HSPF model}

Sensitivity analysis with the model was conducted to determine the main influential parameters which may affect sediment yield simulation and need to be calibrated. Although sensitive parameters for the HSPF model have been discussed in many previous studies, our analysis was done to confirm the literature information for the Sioulin watershed.

The analysis was done in two steps. One was for the hydrologic component of HSPF, and the other was for the sediment runoff component. For the hydrologic parameters, INTFW, IRC, INFILT, UZSN, and LZSN were tested to be more sensitive parameters, in which INTFW is the interflow inflow 


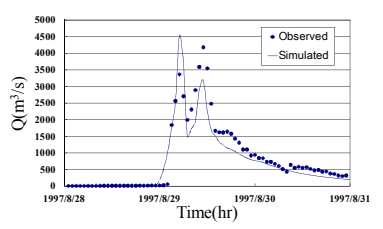

(a) hydrographs at Lyushuei Gauging Station during Typhoon Amber

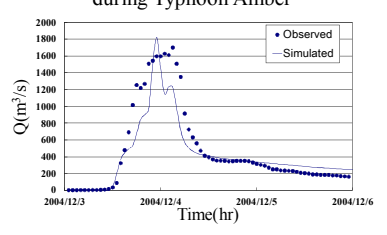

(c) hydrographs at Renshou Bridge Gauging Station during Typhoon Nanmadol

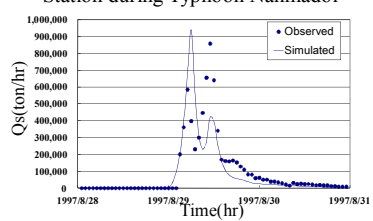

(e) sediment hydrographs at Lyushuei Gauging Station during Typhoon Amber

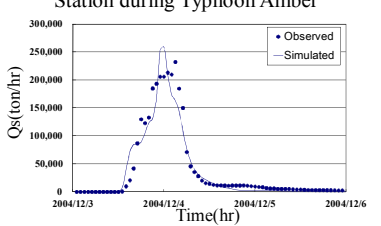

(g) sediment hydrographs at Renshou Bridge Gauging Station during Typhoon Nanmadol

Fig. 6. Comparisons of recorded and HSPF simulation results.

parameter; IRC is the interflow recession parameter; INFILT is the infiltration parameter; UZSN is the upper zone nominal storage; LZSN is the lower zone nominal storage. Among the five parameters, INTFW and IRC are the most sensitive parameters. By altering the value of each parameter, peak flow volume, runoff volume, or flow recession curve can be adjusted. For instance, a decrease effect on total runoff volume and peak flow volume will correspond, while increasing the value of INTFW.

For the sediment runoff parameters, JRER, JSER, JGER, KSAND, and EXPSND were tested to be more sensitive parameters, in which JRER is the exponent in the soil detachment equation; JSER is the exponent for transport of detached sediment; JGER is the exponent for scour of the matrix soil; KSAND and EXPSND are the coefficient and exponent in the sandload power function formula. The above five parameters generally have an increase effect on sediment yield while increasing their values. A brief description for the above mentioned model parameters are listed in Table 3.

\subsubsection{Calibration and validation for HSPF model}

Before modelling a flood event or long-term period, the HSPF model must be calibrated and verified for the studied

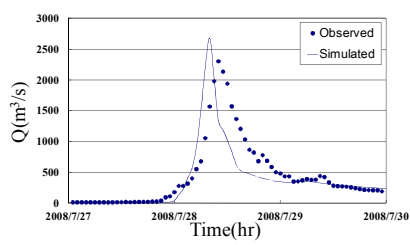

(a) Hydrologic verification at the Lyushuei gauging station during Typhoon Fungwong

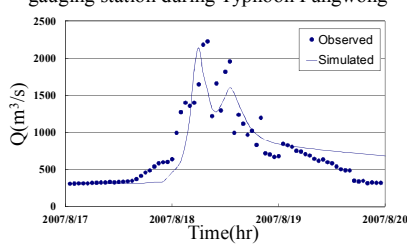

(a) Hydrologic verification at the Renshou Bridge Gauging Station during Typhoon Sepat

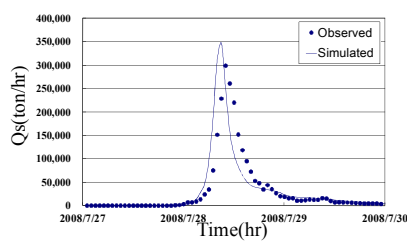

(b) Sediment verification at the Lyushuei gauging station during Typhoon Fungwong

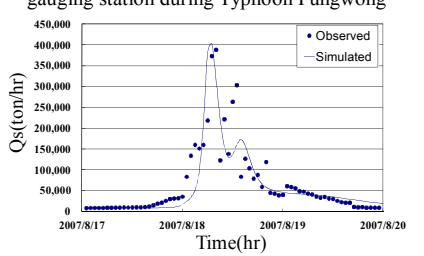

(b) Sediment verification at the Renshou Bridge Gauging Station during Typhoon Sepat
Fig. 7. Verification results for both streamflow and sediment discharge simulation.

watershed. The observed data with hourly time series form from two streamflow and sediment monitoring stations, as shown in Fig. 1, were used for the model calibration and verification. Four steps were performed in the following sequence: hydrological calibration; hydrological verification; sediment yield calibration; sediment yield verification. In this study, the calibration at the Lyushuei gauging station was carried out for two typhoon events of Amber (28 August 1997-30 August 1997) and Bilis (22 August 200024 August 2000), and the parameters found by the calibration were used in the validation of the model for one typhoon event of Fungwong (27 July 2008-29 July 2008). Figure 6a, $\mathrm{b}$, e, and $\mathrm{f}$ shows the calibration results for hydrologic and sediment modules of HSPF, with two typhoon periods at the Lyushuei gauging station. Figure $7 \mathrm{a}$ and $\mathrm{b}$ shows the verification results for both streamflow and sediment discharge simulation at the same station. As seen in six Figures, all observed and simulated results are close to each other. Similarly, the calibration at the Renshou Bridge gauging station was carried out for two typhoon events of Nanmadol (3 December 2004-5 December 2004) and Longwang (1 October 2005-3 October 2005), and the parameters found by the calibration were used in the validation of the model for one typhoon event of Sepat (17 August 2007-19 August 2007). Figure $6 \mathrm{c}, \mathrm{d}, \mathrm{g}$ and h compares graphically measured and predicted daily runoff and sediment yield values for the calibration period with two typhoon periods at the Renshou Bridge gauging station. Figure $7 \mathrm{c}$ and d displays the verification results for both streamflow and sediment discharge simulation at the same station. From the six Figures, in general, simulated runoff or sediment yield follows a trend similar to that of measured runoff or sediment yield.

In addition to the graphical evaluation for the model performance, percent differences (\%Diff) between observed and simulated values were used to assess model accuracy. 
Table 1. Calibration and verification results.

\begin{tabular}{|c|c|c|c|c|c|c|c|c|}
\hline \multirow{2}{*}{$\begin{array}{l}\text { Process } \\
\text { Type }\end{array}$} & \multirow{2}{*}{$\begin{array}{l}\text { Gauging } \\
\text { Station }\end{array}$} & \multirow{2}{*}{$\begin{array}{l}\text { Typhoon } \\
\text { Event }\end{array}$} & \multicolumn{3}{|c|}{$\begin{array}{l}\text { Peak } \\
\text { Value }\end{array}$} & \multicolumn{3}{|c|}{$\begin{array}{c}\text { Total } \\
\text { Volume }\end{array}$} \\
\hline & & & Observed & Calculated & $(\%)$ Diff & Observed & Calculated & (\%)Diff \\
\hline Hydrologic calibration & Lyushuei & Amber & $\begin{array}{l}4181 \\
\left(\mathrm{~m}^{3} \mathrm{~s}^{-1}\right)\end{array}$ & $\begin{array}{l}4520 \\
\left(\mathrm{~m}^{3} \mathrm{~s}^{-1}\right)\end{array}$ & 8.1 & $\begin{array}{l}59926 \\
\left(\mathrm{~m}^{3}\right)\end{array}$ & $\begin{array}{l}51276 \\
\left(\mathrm{~m}^{3}\right)\end{array}$ & 14.4 \\
\hline Hydrologic calibration & Lyushuei & Bilis & $\begin{array}{l}3986 \\
\left(\mathrm{~m}^{3} \mathrm{~s}^{-1}\right)\end{array}$ & $\begin{array}{l}4195 \\
\left(\mathrm{~m}^{3} \mathrm{~s}^{-1}\right)\end{array}$ & 5.2 & $\begin{array}{l}71188 \\
\left(\mathrm{~m}^{3}\right)\end{array}$ & $\begin{array}{l}65348 \\
\left(\mathrm{~m}^{3}\right)\end{array}$ & 8.2 \\
\hline Hydrologic verification & Lyushuei & Fungwong & $\begin{array}{l}2306 \\
\left(\mathrm{~m}^{3} \mathrm{~s}^{-1}\right)\end{array}$ & $\begin{array}{l}2683 \\
\left(\mathrm{~m}^{3} \mathrm{~s}^{-1}\right)\end{array}$ & 6.0 & $\begin{array}{l}32383 \\
\left(\mathrm{~m}^{3}\right)\end{array}$ & $\begin{array}{l}27618 \\
\left(\mathrm{~m}^{3}\right)\end{array}$ & 5.9 \\
\hline Hydrologic calibration & Renshou bridge & Nanmadol & $\begin{array}{l}1703 \\
\left(\mathrm{~m}^{3} \mathrm{~s}^{-1}\right)\end{array}$ & $\begin{array}{l}1822 \\
\left(\mathrm{~m}^{3} \mathrm{~s}^{-1}\right)\end{array}$ & 7.0 & $\begin{array}{l}34020 \\
\left(\mathrm{~m}^{3}\right)\end{array}$ & $\begin{array}{l}30163 \\
\left(\mathrm{~m}^{3}\right)\end{array}$ & 11.3 \\
\hline Hydrologic calibration & Renshou bridge & Lougwang & $\begin{array}{l}1138 \\
\left(\mathrm{~m}^{3} \mathrm{~s}^{-1}\right)\end{array}$ & $\begin{array}{l}1249 \\
\left(\mathrm{~m}^{3} \mathrm{~s}^{-1}\right)\end{array}$ & 9.8 & $\begin{array}{l}28813 \\
\left(\mathrm{~m}^{3}\right)\end{array}$ & $\begin{array}{l}24550 \\
\left(\mathrm{~m}^{3}\right)\end{array}$ & 14.8 \\
\hline Hydrologic verification & Renshou bridge & Sepat & $\begin{array}{l}2231 \\
\left(\mathrm{~m}^{3} \mathrm{~s}^{-1}\right)\end{array}$ & $\begin{array}{l}2142 \\
\left(\mathrm{~m}^{3} \mathrm{~s}^{-1}\right)\end{array}$ & 4.0 & $\begin{array}{l}53514 \\
\left(\mathrm{~m}^{3}\right)\end{array}$ & $\begin{array}{l}55192 \\
\left(\mathrm{~m}^{3}\right)\end{array}$ & 3.1 \\
\hline Sediment calibration & Lyushuei & Amber & $\begin{array}{l}841609 \\
\left(\text { ton } \mathrm{h}^{-1}\right)\end{array}$ & $\begin{array}{l}921036 \\
\left(\operatorname{ton}^{-1}\right)\end{array}$ & 9.4 & $\begin{array}{l}6793851 \\
\text { (ton) }\end{array}$ & $\begin{array}{l}5661333 \\
\text { (ton) }\end{array}$ & 16.7 \\
\hline Sediment calibration & Lyushuei & Bilis & $\begin{array}{l}773114 \\
\left(\text { ton }^{-1}\right)\end{array}$ & $\begin{array}{l}799123 \\
\left(\text { ton }^{-1}\right)\end{array}$ & 3.4 & $\begin{array}{l}8399004 \\
\text { (ton) }\end{array}$ & $\begin{array}{l}7577847 \\
\text { (ton) }\end{array}$ & 9.8 \\
\hline Sediment verification & Lyushuei & Fungwong & $\begin{array}{l}299029 \\
\left(\text { ton }^{-1}\right)\end{array}$ & $\begin{array}{l}346982 \\
\left(\text { ton }^{-1}\right)\end{array}$ & 2.0 & $\begin{array}{l}2272555 \\
\text { (ton) }\end{array}$ & $\begin{array}{l}2319406 \\
\text { (ton) }\end{array}$ & 16.0 \\
\hline Sediment calibration & Renshou bridge & Nanmadol & $\begin{array}{l}232435 \\
\left(\operatorname{ton~}^{-1}\right)\end{array}$ & $\begin{array}{l}259188 \\
\left(\text { ton } \mathrm{h}^{-1} \text { ) }\right.\end{array}$ & 11.5 & $\begin{array}{l}2809541 \\
\text { (ton) }\end{array}$ & $\begin{array}{l}2586185 \\
\text { (ton) }\end{array}$ & 7.9 \\
\hline Sediment calibration & Renshou bridge & Lougwang & $\begin{array}{l}107831 \\
\left(\text { ton } \mathrm{h}^{-1}\right)\end{array}$ & $\begin{array}{l}115482 \\
\left(\text { ton }^{-1}\right)\end{array}$ & 7.0 & $\begin{array}{l}1746771 \\
\text { (ton) }\end{array}$ & $\begin{array}{l}1782855 \\
\text { (ton) }\end{array}$ & 2.0 \\
\hline Sediment verification & Renshou bridge & Sepat & $\begin{array}{l}388749 \\
\left(\text { ton }^{-1}\right)\end{array}$ & $\begin{array}{l}404031 \\
\left(\text { ton }^{-1}\right)\end{array}$ & 3.9 & $\begin{array}{l}4649339 \\
\text { (ton) }\end{array}$ & $\begin{array}{l}4336053 \\
\text { (ton) }\end{array}$ & 6.7 \\
\hline
\end{tabular}

Donigian (2000) in HSPF training workshops provided some general guidelines of \%Diff for calibration/verification tolerances or targets to model users. If the percent difference value is less than $15 \%$, the calibrated/verified model is considered "very good". If the value is in the range between $15 \%$ and $25 \%$, the model is considered "good". If the value is in the range of $25 \%$ to $35 \%$, the model is considered "fair". If the value is beyond $35 \%$, the model is considered "poor". According to the aforementioned guidelines, all simulation results for hourly runoff and sediment discharge are examined as shown in Table 1. The percent difference values of peak flow for all simulations are calculated to be $2.0-11.5 \%$ and are generally within the level of "very good". The percent difference values of total volume for all simulations are calculated to be $2.0-16.7 \%$ and are generally in the range from "very good" to "good". The results of runoff and sediment yield and observations are fairly congruent.

\subsubsection{Simulation procedure for estimating shallow landslide sediment yield}

The procedure as shown in Fig. 3 (the lower left-hand side of the Figure) for simulating shallow landslide sediment yield is given as follows:

1. Rainfall-runoff process: the hydrologic process is modelled by the HSPF/PWATER module. PWATER is used to calculate the components of the water budget, primarily to predict the total runoff from a pervious area.

2. Manipulation of sediment sources: for sediment from soil erosion, the detachment, attachment, and removal involve in the erosion processes on the pervious land surface from a pervious area. The HSPF/SEDMNT module is used to simulate the production and removal of sediment from a pervious land segment. For sediment from shallow landslides, TRIGRS is firstly used to predict the locations of occurrence of shallow landslides in the study area, and then the landslide volume for each landslide spot can be estimated by multiplying the landslide area by the soil depth. Finally, spatial landside volume data as external data will be incorporated into the HSPF/MUSTIN (Multiple Timeseries Sequential Input) module, which is a utility module utilized to read an external file for use by other HSPF modules.

3. Sediment transport process: the sediment transport process is modelled by both HSPF/HYDR and HSPF/SEDTRN module. HYDR is to simulate the hydraulic process occurring in a reach. The main purpose of the process is to route floods. SEDTRN is to simulate the transport, deposition, and scour of inorganic sediment in free flowing reaches. After the above step, the watershed sediment yield can be calculated. 


\subsection{Estimation of debris flow sediment yield (occurrence condition)}

For a debris-flow occurrence condition, sediment transport behaviour and magnitude are distinct from the scenario of non-occurrence condition. When modelling the debris flow, a numerical tool with an appropriate rheological model must be chosen. A numerical model, FLO-2D, developed by O'Brien (2006) was selected for the purpose of the present study. The rheological model adopted in the FLO-2D is a well-known quadratic shear stress model which can describe the continuum of flow regimes from viscous to turbulent/dispersive flow. This model can avoid the modelling problem of not knowing the flow regime in advance. Additionally, FLO-2D has been successfully used for practical cases of debris flow simulations by many researchers from different countries (O’Brien, 2006; Hsu et al., 2010). Thus, the model is very appropriate for the debris flow study.

The commercial software FLO-2D can determine the depositional extent and sediment yield of debris flow. The calibration and verification of the FLO-2D model for the study area has been studied by Hsu et al. (2010). However, their study focused on the simulation of debris-flow depositional extent but not estimation of sediment yield. In the presented paper, we intended to use the calibrated FLO-2D model done by Hsu et al. (2010) to develop the estimation of sediment yield. Some assumptions such as homogeneous fluid, nonerodible bed, and constant rheology along the channel and in time were made in the simulation. The procedure for estimating debris flow sediment yield has been constructed as shown in Fig. 3 (the lower right-hand side of the Figure). The first step is to produce an inflow hydrograph for a simulated debris-flow-prone watershed. To enhance the accuracy of debris-flow simulation, the HSPF model - instead of using the rainfall-runoff module in the FLO-2D model - was adopted to compute an inflow hydrograph. This strategy has been demonstrated by Hsu et al. (2010) with the reason that the HSPF model has a better performance than the FLO-2D model at peak flow and flow recession periods. The second step is determining the debris flow hydrograph by the bulking factor and resulting inflow hydrograph. The bulking factor $\left(\mathrm{BF}=1 /\left(1-C_{\mathrm{v}}\right)\right)$ can be calculated by assigning the volumetric sediment concentration $\left(C_{\mathrm{v}}\right)$, which can be determined by Eq. (1). The volumetric sediment concentration $\left(C_{\mathrm{v}}\right)$ is defined as the volume of sediment divided by volume of water plus sediment. By introducing Takahashi's equilibrium concentration formula (Takahashi, 1980), the volumetric sediment concentration can be estimated by the equilibrium concentration $\left(C_{D}\right)$ divided by the volume concentration of solid fraction on the bed $\left(C_{\mathrm{b}}\right)$, where $C_{\mathrm{b}}$ can be estimated from the porosity of solid fraction on the bed; and $C_{D}$ is given in the following equation:
$C_{D}=\frac{\rho_{\mathrm{w}} \tan \theta}{\left(\rho_{\mathrm{s}}-\rho_{\mathrm{w}}\right)(\tan \phi-\tan \theta)}$

where $\theta$ is the inclined angle of the channel bed and $\phi$ is the internal friction of debris; $\rho_{\mathrm{s}}$ and $\rho_{\mathrm{w}}$ are densities of solids and water, respectively. Since the equilibrium concentration is dependent on the bed inclination, the volumetric sediment concentration in a given potential debris-flow creek is a function of the channel slope. The last step is to proceed with debris-flow sediment estimation simulation by assigning all required input data and the resulting debris flow hydrograph. From this, the sediment yield can be computed, and inundated area of debris flow can be obtained as well.

\section{Results and discussion}

According to Sect. 3, the study has developed an integrated method, considering sediment supplies associated with soil erosion, shallow landslide, and debris flow, to estimate sediment yield from a debris-flow-prone watershed on a storm event basis. This can be used not only to predict potential sediment yield of a watershed for any extreme rainfall event, but also to address possible impact on sediment yield from different sediment sources, landslide sediment delivery ratio, and relationship between sediment yield and watershed area. An example case study from 26 potential debris-flow creeks located in Sioulin Township is presented to illustrate the sediment yield estimate and interesting questions mentioned above. The rainfall data used for the case study is based upon a 24-h design hyetograph with the 100-yr return period. The relevant results are described as follows.

\subsection{Sediment yield and comparisons of sediment yields from different scenarios}

Under the condition of 100-yr rainfall intensity, the proposed method was applied to each potential debris-flow watershed of Sioulin Township to estimate potential sediment yields supplied from three different sediment sources (soil erosion, shallow landslide, and debris flow) as shown in Fig. 8. The Hualien DF019 creek has maximum sediment yields contributed by both soil erosion and debris flow. The maximum sediment yield from shallow landsliding may happen on the Hualien DF012 creek. Possible sediment yields for each village can be found in the Fig. 8 as well. The results indicated that Wunlan and Jingmei villages may receive a relatively greater impact caused by soil erosion and shallow landsides; the relatively large sediment yield arising from debris flow may happen in the villages of Chongde, Wunlan, and Jingmei.

By comparing sediment yields from different scenarios, the results showed that the sediment yield considering landslides were found to be increasing at about 1.1 to 13.8 times than that estimated under the soil erosion conditions. In other 


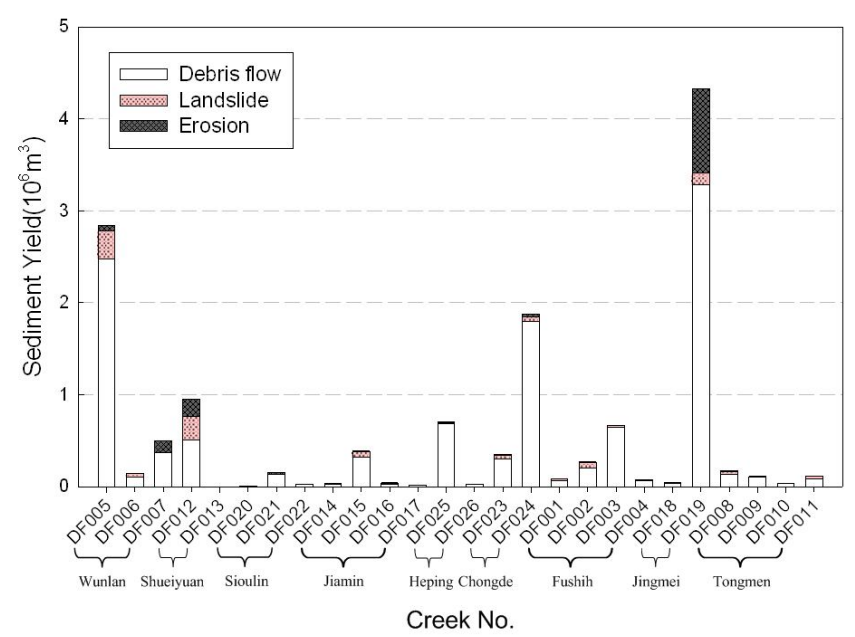

Fig. 8. Sediment yields supplied from three different sediment sources in each potential debris-flow watershed.

words, for shallow landslide-prone watersheds shallow landslides can provide large amount of sediment, approximately $11-92 \%$ of total sediment yield. It is more realistic to estimate the watershed sediment yield when considering the mechanism of landslide and soil erosion all together, especially in hilly watersheds. In addition, a comparison of sediment yields computed from occurrence and non-occurrence of debris flow scenarios showed that the sediment yield considering an occurrence condition was found to be increasing at about 14.2 times more on average than that estimated under a non-occurrence condition. This implied watershed sediment hazard induced by debris flow may cause severe consequences.

\subsection{Landslide sediment delivery ratio}

Landslide sediment delivery ratio is an important indicator of how much sediment produced on hillslopes could be transported into the channel network and discharged at the watershed outlet for a given time period. The sediment delivery ratio is influenced by a wide range of geomorphological and environmental factors and therefore can be any number from $0 \%$ to $100 \%$. Several studies have shown that delivery ratios of landslides vary from $20 \%$ to $70 \%$ when slope failure happens in mountainous environments (Trustrum et al., 1999; Lin et al., 2008). In this study, TRIGRS has been used to predict shallow landslide volume for the study area. Results showed shallow landslides triggered by the $100-\mathrm{yr}$ rainfall occur in all creeks except the three creeks of Hualien DF020, DF021 and DF022. Subsequently, for the failed materials in each creek, HSPF was utilized to simulate sediment transport and estimate the following sediment yield at each watershed outlet. Finally, delivery ratio of landslide debris is calculated by the above two quantities. The results of this analysis indicated the magnitude of the landslide sediment

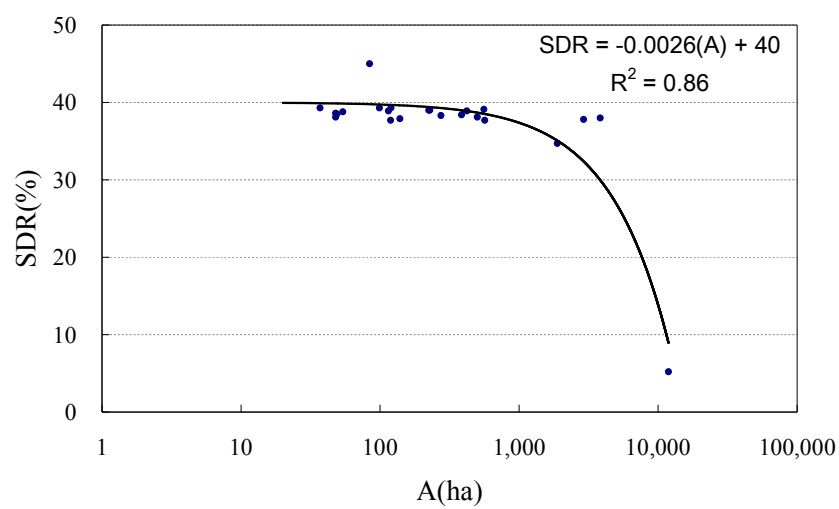

Fig. 9. Relationship between sediment delivery ratio and watershed area

delivery ratio for the calculated creeks ranged from 5.2\% to $45.0 \%$. The overall average landslide sediment delivery ratio was approximately $38.4 \%$. Landslide sediment delivery ratio may vary widely for any given size watershed area, but limited data, as shown in Fig. 9, indicate that they vary inversely with the size of the watershed area. This relationship is consistent with a literature reported by US Conservation Service (ASCE, 1975). In the literature, the inverse relationship between delivery ratio and area has been explained in terms of the decreasing slope and channel gradients and increasing opportunities for deposition associated with increasing watershed size.

\subsection{Relationship between sediment yield and watershed area}

Developing regression equations to predict sediment yields associated with soil erosion, shallow landsliding, or debris flow provides a useful tool to quickly understand possible sediment yield impact for any targeted watershed. Some useful empirical equations have been proposed by previous work (ASCE, 1975; Franzi and Bianco, 2001). However, those are site-specific relations.

The overall results of sediment yield estimate from the 26 debris-flow-prone watersheds were adopted to establish several relationships with watershed area. By adopting the regression analysis technique, the dependence between sediment yield (SY) and watershed area (A) for different scenarios can be identified. Figure 10 shows that a linear relationship exists between the sediment yield and watershed area with a coefficient of determination $R^{2}$ of 0.969 (or correlation coefficient $R$ of 0.984 ). This relationship is applicable to a shallow landslide-prone watershed, where the sediment yield is contributed by soil erosion and shallow landsliding. Other regression results for the other two scenarios can be found in Table 2. The coefficients of determination $R^{2}$ for soil erosion and debris flow case are 0.930 (or $R=$ 0.964 ) and 0.710 (or $R=0.842$ ), respectively. Generally, a 
Table 2. The Results of Regression Analysis.

\begin{tabular}{lrrr}
\hline Scenarios & $\begin{array}{r}\text { Regression } \\
\text { equation } \\
\mathrm{SY}\left(\mathrm{m}^{3}\right) ; \mathrm{A}(\mathrm{ha})\end{array}$ & $\begin{array}{r}\text { Coefficient } \\
\text { of determination } \\
R^{2}\end{array}$ & $\begin{array}{r}\text { Coefficient } \\
\text { of correlation }\end{array}$ \\
\hline Soil erosion & $\mathrm{SY}=70.71 \mathrm{~A}$ & 0.930 & 0.964 \\
Soil erosion and shallow landslide & $\mathrm{SY}=91.77 \mathrm{~A}$ & 0.969 & 0.984 \\
Debris flow & $\mathrm{SY}=284.63 \mathrm{~A}+170863$ & 0.710 & 0.842 \\
\hline
\end{tabular}

Table 3. Descriptions of HSPF Model Parameters.

\begin{tabular}{lll}
\hline Parameter name & Description & Units \\
\hline INTFW & Interflow inflow parameter & None \\
IRC & Interflow recession parameter & None \\
INFILT & Infiltration rate & $\mathrm{mm} \mathrm{h}^{-1}$ \\
UZSN & Upper zone nominal soil moisture storage & $\mathrm{mm}$ \\
LZSN & Lower zone nominal soil moisture storage & $\mathrm{mm}$ \\
JRER & Exponent in the soil detachment equation & None \\
JSER & Exponent in the detached sediment washoff equation & None \\
JGER & Exponent in the matrix soil scour equation, which simulates gully erosion & None \\
KSAND & Coefficient in the sandload suspension equation & None \\
EXPSND & Exponent in sandload suspension equation & None \\
\hline
\end{tabular}

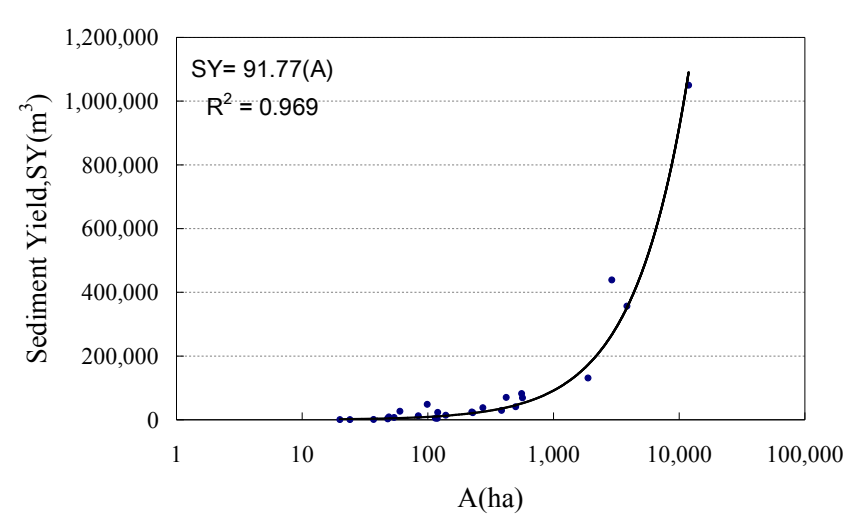

Fig. 10. Relationship between sediment yield and watershed area for shallow landslide-prone watersheds.

correlation that is greater than 0.8 is described as strong. Thus, the results demonstrated that sediment yield on the basis of the same rainfall magnitude has a strong relationship to watershed area. The regression equations listed in Table 2 are based on the rainfall intensity of the 100 -yr return period. For other rainfall magnitudes, new regression equations need to be established.

\section{Conclusions}

Information on sediment yield from a watershed is quite essential because it is often needed to estimate the quantity of sediment delivered downstream for watershed management and hazard mitigation purposes. In the past, most of models for estimating sediment yield only exist for consideration of soil erosion. For a hilly watershed, shallow landslides can be significant sources of sediment and may in turn act as a major control on the occurrence of debris flow in rivers. This paper presents an integrated method, considering sediment supplies associated with soil erosion, shallow landslide, and debris flow to estimate sediment yield from a debris-flowprone watershed on a storm event basis. The main conclusions which can be drawn from this study are as follows:

1. The integrated method, combined with HSPF, TRIGRS, and FLO-2D models, has been successfully applied to 26 debris-flow-prone creeks and demonstrates an ability to simulate the spatial distribution of shallow landslide and determine watershed sediment yield associated with different transport mechanisms such as fluvial transport and debris flow scenarios.

2. The scenario applications show the integrated method can be used to explore various impacts on sediment yield. For shallow landslide-prone watersheds, shallow landslide has been proved to be the most significant contributor of the total watershed sediment yield as compared with soil erosion. In addition, if the shallow landslide can develop into debris flows, the sediment volume would be relatively high in magnitude. The present results show that the sediment yield in a debris-flow occurrence condition was found increasing at about 14.2 times in average than that estimated under a non-occurrence condition. Hence, the shallow 
landslides may act as a major control on the occurrence of debris flow.

3. The estimate of shallow landslide transport capacity into a main channel indicated the overall sediment delivery ratio on a 100 -yr flood return period basis was approximately $38.4 \%$. Additionally, the delivery ratio may vary inversely with the size of the watershed area.

4. The relationship between the sediment yield and watershed area has been established using 26 debris-flowprone watersheds analyzed data. The result showed that a linear relationship exists between two variables with a high coefficient of determination for three scenarios. The regression equations provide a useful tool to estimate possible sediment yield based on the computed watershed area.

5. For future study, triggering conditions of debris flow and channel bed scouring and deposition can be incorporated into the integrated method to improve the completeness of the method in estimating sediment yield with a given watershed and rainfall conditions.

Acknowledgements. The study was supported by a grant from the Hualien Office of Soil and Water Conservation Bureau, the Council of Agriculture and the Executive Yuan, Taiwan. The authors would also like to acknowledge all the individuals who participated in the field data collections and investigation of debris-flow-prone creeks.

Edited by: L. Franzi

Reviewed by: two anonymous referees

\section{References}

Acharya, G., Cochrane, T. A., Davies, T., and Bowman, E.: The influence of shallow landslides on sediment supply: A flume-based investigation using sandy soil, Eng. Geol., 109, 161-169, 2009.

Acharya, G., Cochrane, T. A., Davies, T., and Bowman, E.: Quantifying and modeling post-failure sediment yields from laboratoryscale soil erosion and shallow landslide experiments with silty loess, Geomorphology, 129, 49-58, 2011.

Aksoy, H. and Kavvas, M. L.: A review of hillslope and watershed scale erosion and sediment transport models, Catena, 64, 247271, 2005.

Allen, P. A. and Hovius, N.: Sediment supply from landslidedominated catchments: implication for basin-margin fans, Basin Res., 10, 19-35, 1998.

Amold, J. G., Srinivasan, R., Muttiah, R. S., and Williams, J. R.: Large area hydrological modelling and assessment Part I: model development, J. Am. Water Resour. Assoc., 34, 73-89, 1998.

Amore, E., Modica, C., Nearing, M. A., and Santoro, V. C.: Scale effect in USLE and WEPP application for soil erosion computation from three Sicilian basins, J. Hydrol., 293, 100-114, 2004.

A.S.C.E. (American Society of Civil Engineering): Sedimentation Engineering. Am. Soc. Civ. Eng., New York, N.Y., Manuals and Reports on Engineering Practice, No. 54, 1975.
Bathurst, J. C., Burton, A., Clarke, B. G., and Gallart, F.: Application of the SHETRAN basin-scale, landslide sediment yield model to the Llobregat basin, Spanish Pyrenees, Hydrol. Process., 20, 3119-3138, 2006.

Baum, R. L., Savage, W. Z., and Godt, J. W.: TRIGRSA fortran program for transient rainfall infiltration and grid-based regional slope-stability analysis, US Geological Survey Open-File Report 02-0424, 2002.

Beasley, D. B., Huggins, L. F., and Monke, E. J.: ANSWERS: a model for watershed planning, Transactions of the ASAE, 23, 938-944, 1980.

Bhayan, S. J., Kalita, P. K., Janssen, K. A., and Barnes, P. L.: Soil loss predictions with three erosion simulation models, Environ. Modell. Softw., 17, 137-146, 2002.

Bicknell, B. R., Imhoff, J. C., Kittle Jr., J. L., Jobes, T. H., and Donigian Jr., A. S.: HSPF, Version 12, User's Manual, US Environmental Protection Agency, Athens, GA, 2001.

Burton, A. and Bathurst, J. C.: Physically based modelling of shallow landslide sediment yield at a catchment scale, Engineering Geology, 35, 89-99, 1988.

Claessens, L., Knapen, A., Kitutu, M. G., Poesen, J., and Deckers, J. A.: Modelling landslide hazard, soil redistribution and sediment yield of landslides on the Ugandan footslopes of Mount Elgon, Geomorphology, 90, 23-35, 2007.

Chou, W. C.: Modelling Watershed Scale Soil Loss Prediction and Sediment Yield Estimation, Water Resour. Manage., 24, 20752090, 2010.

Donigian Jr., A. S.: HSPF Training Workshop Handbook and CD, Lecture \#19, Calibration and Verification Issues, Slide \#L19-22, EPA Headquarters, Washington Information Center, Presented and prepared for US EPA, Office of Water, Office of Science and Technology, Washington, DC, USA, 2000.

Franzi, L. and Bianco, G.: A statistical method to predict debris flow deposited on a debris fan, Phys. Chem. Earth, Pt. C, 26, 683-688, 2001.

Godt, J. W., Baum, R. L., and Chleborad, A. F.: Rainfall characteristics for shallow landsliding in Seattle, Washington, USA, Earth Surf. Proc. Landf., 31, 97-110, 2006.

Hsu, S. M., Chiou, L. B., Lin, G. F., Chao, C. H., Wen, H. Y., and $\mathrm{Ku}, \mathrm{C}$. Y.: Applications of simulation technique on debris-flow hazard zone delineation: a case study in Hualien County, Taiwan, Nat. Hazards Earth Syst. Sci., 10, 535-545, doi:10.5194/nhess10-535-2010, 2010.

Istanbulluoglu, E., Tarboton, D. G., and Pack, R. T.: Modeling of the interactions between forest vegetation, disturbances, and sediment yields, J. Geophys. Res., 109, 1-22, 2004.

Iverson, R. M.: Landslid triggering by rain infiltration, Water Resour. Res., 36, 1897-1910, 2000.

Johanson, R. C., Imhoff, J. C., and Davis, H. H.: Users Manual for the Hydrologic Simulation Program-Fortran (HSPF) version No. 5.0, EPA-600/9-80-105, US EPA Environmental Research Laboratory, Athens, GA, 1980.

Knisel, W. G.: CREAMS: A Field Scale Model for Chemicals, Runoff and Erosion from Agricultural Management Systems, USDA, 1980.

Laflen, J. M., Lane, L. J., and Foster, G. R.: WEPP: A new generation of erosion prediction technology, J. Soil Water Conserv., 46, 34-38, 1991. 
Lee, K. T. and Ho, J. Y.: Prediction of landslide occurrence based on slope-instability analysis and hydrological model simulation, J. Hydrol., 375, 489-497, 2009.

Lin, G. W., Chen, H., Petley, D. N., Chou, W. C., Horng, M. J., Wu, S. J., and Chuang, B.: Impact of rainstorm-triggered landslides on high turbidity in a mountain reservoir, Eng. Geol., 17, 97103, 2011.

Lin, G. W., Chen, H., Hovius, N., Horng, M. J., Dadson, S., Meunier, P., and Lines, M.: Effects of earthquake and cyclone sequencing on landsliding and fluvial sediment transfer in a mountain catchment, Earth Surf. Proc. Landf., 33, 1354-1373, 2008.

Malet, J. P., Laigle, D., Remaitre, A., and Maquaire, O.: Triggering conditions and mobility of debris flows associated to complex earthflows, Geomorphology, 66, 215-235, 2005.

Montgomery, D. R. and Dietrich, W. E.: A physically-based model for the topographic control on shallow landsliding, Water Resour. Res., 30, 1153-1171, 1994.

Merritt, W. S., Letcher, R. A., and Jakeman, A. J.: A review of erosion and sediment transport models, Environ. Model. Softw., 18, 761-799, 2003.

Morgan, R. P. C., Quinton, J. N., Smith, R. E., Govers, G., Poesen, J. W. A., Auerswald, K., Chisci, G., Torri, D., and Styczen, M. E.: The European soil erosion model (EUROSEM): a dynamic approach for predicting sediment transport from fields and small catchments, Earth Surf. Proc. Landf., 23, 527-544, 1998.

Nasr, A., Bruen, M., Jordan, P., Moles, R., Kiely, G., and Byrne, P.: A comparison of SWAT, HSPF and SHETRAN/GOPC for modelling phosphorus export from three catchments in Ireland, Water Res., 41, 1065-1073, 2007.

O'Brien, J. D.: FLO-2D user's manual, Version 2006.01, Flo Engineering, Nutrioso, 2006.

Pack, R. T., Tarboton, D. G., Goodwin, C. N., and Prasad, A.: SINMAP 2. A Stability Index Approach to Terrain Stability Hazard Mapping, technical description and users guide for version 2.0, Utah State University, 2005.

Prosser, I. P., Young, B., Rustomji, P., Hughes, A., and Moran, C.: A model of river sediment budgets as an element of river health assessment, in: Proceedings of the International Congress on Modelling and Simulation (MODSIM'2001), 10-13, 861-866, 2001.

Reichenbach, P., Cardinali, M., De Vita, P., and Guzzetti, F.: Regional hydrological thresholds for landslides and floods in the Tiber River Basin (central Italy), Environ. Geol., 35, 146-159, 1998.
Rutledge, A. T.: Computer programs for describing the recession of ground-water discharge and for estimating mean ground-water recharge and discharge from streamflow data - update: US Geological Survey Water-Resources Investigations Report 98-4148, 1998.

Schuerch, P., Densmore, A. L., McArdell, B. W., and Molnar, P.: The influence of landsliding on sediment supply and channel change in a steep mountain catchment, Geomorphology, 78, 222235, 2006.

Schwab, M., Rieke-Zapp, D., Schneider, H., Liniger, M., and Schlunegger, F.: Landsliding and sediment flux in the Central Swiss Alps: a photogrammetric study of the Schimbrig landslide, Entlebuch, Geomorphology, 97, 392-406, 2008.

Selby, M. J.: Hillslope Materials and Processes, Oxford Univ. Press, 451 pp., 1993.

Smith, R. E.: A kinematic model for surface mine sediment yield, Transactions of the ASAE, 24, 1508-1514, 1981.

Takahashi T.: Debris flow on prismatic open channel, J. Hydraul. Division, ASCE, 6, 381-396, 1980.

Trustrum, N. A., Gomez, B., Page, M. J., Reid, L. M., and Hicks, M.: Sediment production, storage and output: the relative role of large magnitude events in steepland catchments, Zeitschrift fuer Geomorphologie Neue Folge, Supplementband, 115, 71-86, 1999.

Verstraeten, G. and Poesen, J.: Factors controlling sediment yield from small intensively cultivated catchments in a temperate humid climate, Geomorphology, 40, 123-144, 2001.

Viney, N. R. and Sivapalan, M.: A conceptual model of sediment transport: application to the Avon River Basin in Western Australia, Hydrol. Process., 13, 727-743, 1999.

Wicks, J. M. and Bathurst, J. C.: SHESED: a physically based, distributed erosion and sediment yield component for the SHE hydrological modeling system, J. Hydrol., 175, 213-238, 1996.

Wischmeier, H. and Smith, D. D.: Predicting rainfall erosion losses, Agriculture Handbook no 537, USDA Science and Education Administration, 1978.

Young, R. A., Onstad, C. A., Bosch, D. D., and Anderson, W. P.: AGNPS: a nonpoint-source pollution model for evaluating agricultural watersheds, J. Soil Water Conserv., 44, 168-173, 1989.

Ziegler, A. D., Giambelluca, T. W., and Sutherland, R. A.: Erosion prediction on unpaved mountain roads in northern Thailand: validation of dynamic erodibility modeling using KINEROS2, Hydrol. Process., 15, 337-358, 2001. 